\title{
Development of Integrated Thematic Learning Model based on Islamic Values in Madrasah Ibtidaiyah of Padang City
}

\author{
Sasmi Nelwati ${ }^{1}$, Sufyarma Marsidin ${ }^{2}$, Nizwardi Jalinus ${ }^{3}$, Mukhaiyar $^{4}$ \\ ${ }^{1}$ Universitas Islam Negeri Imam Bonjol, Padang and Indonesia, \\ ${ }^{234}$ Universitas Negeri Padang, Padang and Indonesia \\ Corresponding author, e-mail: sasminelwati@gmail.com
}

\begin{abstract}
The purpose of this research is to develop an integrated thematic learning model based on Islamic values in Madrasah Ibtidaiyah practically and effectively. The type of this research is development research that refers to the model of $4 \mathrm{D}$. The distribution of this model is implemented in Madrasah Ibtidaiyah of Padang city in 2016. The types of data are qualitative and quantitative data. Qualitative data are derived from observation and interview. Furthermore, quantitative data are obtained from questionnaire. The products of integrated thematic learning model based on Islamic values which have been developed are model guidebook, educator guidebook, and student guidebook. The achievement of the research results indicate that the three products have meet the criteria of validality, practicality and effectiveness. The book model can be used by educators/teachers and students of elementry school level in helping the students become active and having a good character.
\end{abstract}

Keywords: Integrated Thematic Learning Model, Islamic Values, Madrasah Ibtidaiyah

How to Cite: Nelwati, S., Marsidin, S., Jalinus, N., \& Mukhaiyar, M. (2018). Development of Integrated Thematic Learning Model based on Islamic Values in Madrasah Ibtidaiyah of Padang City. International Journal of Research in Counseling and Education, 2 (2) 88 - 92, https://doi.org/10.24036/0028za0002

\section{Introduction}

The development of science and technology has brought a change of educational paradigm towards the shift of ethics and morals of learners. The paradigm shift in education requires the emphasis of learning on strengthening the Islamic values that are able to construct solutions, so that the interaction between educators and learners that contains the transformation of Islamic values and related to various aspects of the lives of learners. In addition, morality itself is the "core" or main pillar of education in general in order to see its position in the national education objectives of UUSPN Number 20 of 2003. It can be achieved by developing all the potential that exists in human beings. The cultivation and formation of noble character toward learners become something that needs to get serious attention for educators and educational staff, especially at the level of Madrasah Ibtidaiyah (MI) education. In other words, MI is the level of basic education of learners where the success or failure of learners in continuing education to a higher level is largely determined by their the ability and experience at this level. Thus, learning at MI level needs to take into account the characteristics and development of learners' ability as a meaningful, especially in this globalization era.

Learning itself is a system, which consists of various components that are connected each other. This is explained by Rusman (2015: 86), learning is a process of communication interaction between learning resources, teachers, and students. This communication interaction is done either directly in the face to face activities or indirectly by using the media, in accordance with the learning model that will be applied. Thus, the learning model becomes the determinant of how the learning process takes place, so that educators need to know the learning model in accordance with the characteristics of learners then learning objectives can be achieved.

There are various types of learning that can be adapted by the teacher, one of them thematic learning model. According to the Ministry of Education, thematic learning is a learning strategy that involves several 
subjects to provide meaningful experience to learners. The integration in this learning can be seen from aspects of process or time, curriculum aspects and aspects of teaching and learning (MoNE, 2003). The implementation of the integration curriculum as proposed, lately known as Integrated Thematic Learning. Integrated thematic learning (integrated instruction) is a learning system that enables learners both individually and in groups, actively explore and discover the concept and principles of science holistically, meaningful and authentic. This is in accordance with the results of previous research conducted by Narti et al (2015). This research was conducted in two elementary schools of Malang. The results of this study indicate that thematic learning makes the learning process more meaningful. In addition, this learning model is also able to attract learners to be more active and also provide ease in understanding the material because learning is implemented based on the interests and needs of learners. Thus, it can be concluded that integrated thematic learning is very important for learners because integrated thematic learning is more emphasizing to the involvement of learners in the learning process or directing learners actively involved in the learning process.

In addition, the implemented Curriculum 2013 (K-13) has conformity to this integrated thematic learning model. This refers to government regulation no. 32 Year 2013 Article 19 paragraph; (1) mentions: the learning process in the education unit is held interactively, inspiration, fun, challenging and motivate the students to actively participate. It also provides sufficient space for initiative, creativity, and independence in accordance with the talents, interests, and physical and psychological development of learners. The 2013 curriculum is applied as a complement to the previous curriculum and prioritizes religious attitudes, social attitudes and knowledge. In other words, the curriculum 2013 prioritizes religious values as cultural endurance in social life and society, it is hoped that graduates of educational institutions can have strong Islamic values in facing the challenges of global society. Taking into account the description of integrated thematic learning and the characteristics of learners, K-13 becomes part of the strategy to improve educational achievement, because K-13 orientation improves students' ability and balance between attitude competence, skill, and knowledge ) at every level of education including at MI level.

Madrasah Ibtidaiyah (MI) as an educational institution characterized by Islam with K-13, provides great opportunities to develop integrated thematic learning based on Islamic values in order to form learners noble characteristic as MI. In addition, MI has a load of Islamic religious education curriculum more than other public elementary schools (SDN). Therefore, educators can develop learning materials in accordance with the needs of learners by integrating Islamic values in everyday life.

Looking at the explanation above, researchers have conducted preliminary research. The observation was conducted in November 2015 in several MI schools in Padang City, representing MI with accredited A and B as well as on private MI with accreditation C. The author's observations were conducted at MIN 1, MIN 2, MIN 3 and MIN 6 Padang City, Private Matured Madrasah (MIS) of Sungai Sapiah and MIS Bakti Tunggul Hitam.

Field observations indicate that integrated thematic learning has been carried out in MIN and MIS, but still refers to what the Department of Education issued, so that students have not maximally show better morals than other elementary schools. In addition, the field situation also shows that the implementation of integrated thematic learning has not been maximally implemented and there is a lack of transformation of Islamic values. Thus, learners have not maximally internalized Islamic values in everyday life. Furthermore, the learning of Islamic Religious Education in MI dominates the cognitive domain of cognitive, resulting in unbalanced between the learner's religious knowledge and the value of his attitudes, it can be seen from the value of the learners report in every semester, it shows high achievement, but morals are not in accordance with his achievements. This is why integration of Islamic values in learning in order to minimize the moral shift of learners and form learners noble character is necessary.

Based on the above description, it is understood that Islamic values are the reference standard in determining the good or bad of a person's morals. The acceptance or rejection of an individual is based more on the conscience. The value derived from Islamic teachings is universal and absolute. The behavior based on the source of teaching is called noble character, while the behavior based on cultural values or customs is very relative and tentative and depends on the local community, called cultured and densely.

Integrated Thematic Learning based on Islamic values needs to get attention in line with changes and culture of life. Changes in the sense of cultivation and the formation of noble character on every subject in all classes, especially in integrating and transforming Islamic values. Achieving Islamic values needs to be continuously improved in anticipation of various phenomena that occur in the future and in shaping the morals of learners. Given the importance of learning achievement that can realize the graduation of noble, especially in MI as a basic educational institution that needs an integrated thematic learning model based on Islamic values in order to form noble character to the learners. Hence, developing integrated thematic learning model based on Islamic values is needed especially at the basic level of education. Therefore, the purpose of this development study is to know the description of integrated thematic implementation in MI 
and see the validity, practicality and effectiveness of integrated thematic learning model based on Islamic values in MI.

\section{Method}

Type of research used is research development. The development model used in this research is the 4-D model (four D models). The 4-D model has three development stages: define, design, development, and disseminate. The subjects of this research are students and teachers of class IV at MIN Gunung Pangilun Padang. The type of data taken in this study is qualitative and quantitative data. Qualitative data in the form of responses and suggestions provided by instrument validators, design experts (curriculum), content experts (materials), expert research focus, practitioners (users). While the quantitative data taken from the questionnaire given to the subject of design experts (design) and material experts.

The steps of the learning device development plan above are explained in detailed as follows:

\section{Definition (define)}

The defining stage is aimed to define the requirements needed in the development of the Integrated Thematic-based learning model based on Islamic Values (TT-BNI). At this stage, it is done by analyzing the objectives within the limits of the developed learning model. Instruments used at this stage are observation sheets and interview guides. In this phase of the definition of analysis carried out the three aspects, namely; aspects of needs, curriculum aspects and learners.

\section{Design (design)}

The design stage is aimed to design a learning model in accordance with an integrated thematic model of pursuit based on predetermined Islamic values, activities at this stage are as follows, designing the model book of Learning, Designing the Workbook of Educators, Designing the workbook of learners.

\section{Development Stage (Develop)}

The development stage is purposed to produce an integrated thematic learning model design based on Islamic values based on the concepts, theories and principles of the development of the learning model that has been built in the theoretical study. The development stage is carried out with several stages:

\section{a. Validation Stage}

Learning models that have been designed prior used are validated first by experts in accordance with their fields. This validation includes content and construct validation. The purpose of validation is to determine whether a product is functioning based on material, construction and language criteria. The main parts that are validated are the suitability of SK, KD, KI, indicators, concepts and language used.

\section{b. Revision Stage}

At this stage an improvement on the learning model developed in accordance with the input of each validator. Learning model that has been improved, then given back to each validator, to do the second stage of validation.

\section{c. Product Test Stage}

The purpose of product trial phase is to find out the practicality of the developed learning model. To see whether or not practical testing is done in the learning process by using a model of learning that has been revised by the validator.

There are some steps in testing of product development of TT-BNI learning model:

- Draft I Development of Revision Analysis Model

- Draft II Development of Revision Model Analysis of TT-BNI

- Final Product: "Integrated Thematic Learning Model Based Islamic Values in shaping noble learners in MI Kota Padang.

\section{Deployment stage (Disseminate)}

This stage is the phase of using TT-BNI learning model that is done on another subject. At this stage of deployment will be a subsequent trial on a limited scale to the revised learning model based on previous trials. At this step an evaluation of the model, whether the TT-BNI learning model developed can be used to achieve effective goals in improving learners' learning outcomes. 


\section{Results and Discussion}

The learning model of TT-BNI (Thematic-Based Integrated Islamic Values) in MI (Madrasah Ibtidaiyah), and it can be used in the learning process. At this stage of development consists of three stages, namely product validation stage, practicality test phase, and effectiveness test phase. The designed learning model is validated by the validator. Validation is done by three validators consisting of one Curriculum expert, Thematic expert, Islamic Education expert, and two Practitioners/ Users.

Specifically, the validation of the teacher education worker's manual (PKPD) is done by asking some validators who are experts in curriculum, thematic learning, and teaching practitioners in MI. This validation sheet is based on the development guidance of the 2013 curriculum RPP with scientific-based steps. The result of validation of teaching materials by expert validator obtained an average value of 3.67 with very good category. Thus it can be concluded from the teaching expert that this instrument is very good and can be used for thematic learning research based on Islamic values in forming learners' noble character.

While practical trials are also conducted in the form of limited tests and widespread testing. The practicality of the model is the result of questionnaire analysis by teachers. Observational data of the implementation of TT-BNI learning model in order to form learners of noble character in the fourth grade of MI has several aspects of assessment, including: guidance aspect, coverage aspect, and language aspect. After the experiment, the study continued with the effectiveness test of the learning model. Based on the results of the experiment can be concluded that this model is able to involve learners actively during the learning process takes place and can gradually change the behavior of learners, can be observed at least in the neighborhood of MI.

Furthermore, to see effectiveness of learning model TT-BNI is done by assessing learners' learning outcomes, because the results of learning is the outcome of assessment related to the understanding of learners. Here are the learners' learning outcomes ranging from sub themes 1,2 and 3, using the TT-BNI model.

Table 1 Evaluation Value from Sub Themes 1 Up to Sub Themes 3

\begin{tabular}{|c|c|c|c|}
\hline $\begin{array}{c}\text { Su } \\
\text { Theme }\end{array}$ & $\begin{array}{c}\text { Number of } \\
\text { Students }\end{array}$ & $\begin{array}{c}\text { The } \\
\text { Lowest Score }\end{array}$ & $\begin{array}{c}\text { The } \\
\text { Highest Score }\end{array}$ \\
\hline 1 & 40 & 60 & 70 \\
\hline 2 & 40 & 65 & 79 \\
\hline 3 & 40 & 70 & 90 \\
\hline
\end{tabular}

The improvement of the learners' the value who learn by using the model of learning TT-BNI, as seen in sub theme 1 that the lowest value is 60 and the highest is 70 . Thus it can be understood that the learning outcomes of learners using TT-BNI model there is a significant increase and has met the completeness of learning outcomes.

In relation to the learning outcomes of learners with the lowest values, can be seen in the following graph:

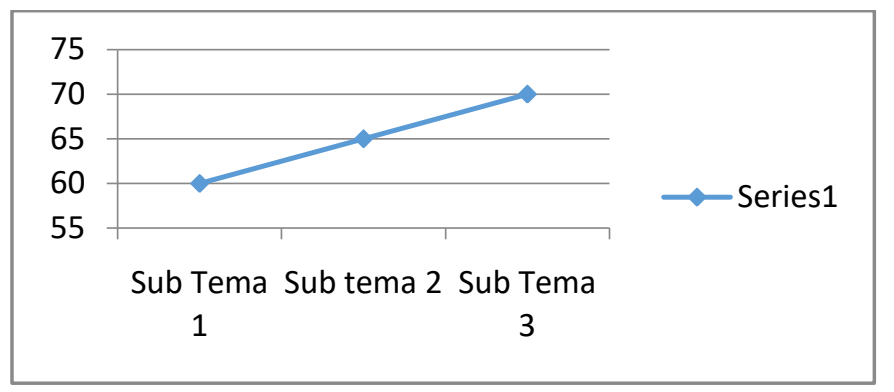

Figure 1: Learning Outcomes of Learners with Low Categories

Furthermore, related to the learning outcomes of students with high categories can be seen in the following table: 


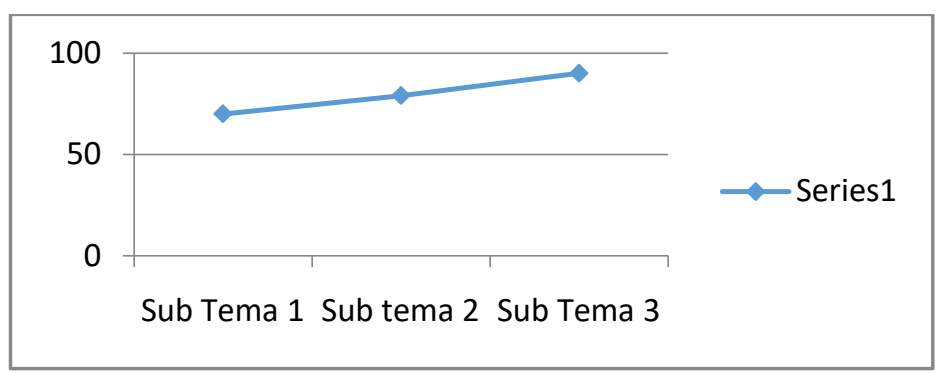

Figure 2: Learners Learning Outcomes with High Categories

From the graph above obtained that the findings in the implementation of thematic learning based on Islamic values showed significant results in the learning process. After the researchers conducted experimental activities, the next activity that the author did was to test the effectiveness or not the learning model. To find out whether or not the learning model is done by observing the results of the students' activity assessment and the difficulty of teachers in implementing them, and the adequacy of time seen from the learning activities take place. Furthermore, the assessment of thematic learning models based on Islamic values is based on process assessment. The process of assessment is assessed from the activities of learners during the course of learning. The average of the activities of learners reached $90 \%$ with a very active category. Learners look motivated to follow the learning process by using this model, it means that this learning model can involve learners actively during the learning process takes place.

\section{Conclusion}

It can be concluded that the integrated thematic learning model based on Islamic values helps learners to be active in the learning process and can achieve good learning outcomes. In addition, by incorporating the values of Islam into the learning process can form the character of learners who are not only knowledgeable but also noble. There are three development criteria in this model, namely valid, effective and practical. A model book resulting from this development study; educator guidance book and learners book, have met these development criteria. In addition, an integrated thematic learning model based on Islamic values can be used by educators, teachers and learners in order to improve the knowledgeable human resources and noble character.

\section{Acknowledgment}

This great task is impossible to be accomplished without helps and supports from many persons. Therefore, a sincere gratitude and appreciation is highly addressed to the Rector of State University of Padang, Postgraduate Director of State University of Padang, Teachers and learners of Madrasah Ibtidaiyah in Padang city who has sincerely helped the writer to conduct this research runs well.

\section{References}

Narti, Yani., Setyosati, Punaji, (2015). Thematic Learning Implementation in Elementary School (Phenomenology Studies in Pamotan SDN 01 and 01 Mojangtengah Dampit Malang). International Journal of Science and Research (IJSR). Vol 5, Issue 11

Rusman (2012). Model-model Pembelajaran, Jakarta: PT. Rajawali Grafindo Persada.

Rusman, (2011). Model-model Pembelajaran: Mengembangkan Profesionalisme Pendidik. Jakarta: Rajawali Pers.

Sugiyono, (2010). Metode Penelitian Pendidikan (Pendekatan Kuantitatif, Kualitatif, dan R\&D). Bandung: Alfabeta 